\title{
Effects of dredging and macrophyte management on the fish species composition in an old Neotropical reservoir
}

\author{
Efeitos do desassoreamento e manejo de macrófitas sobre a composiçáo da fauna de \\ peixes em um reservatório Neotropical antigo
}

\section{André Luiz Henríques Esguícero ${ }^{1 *}$ and Marlene Sofia Arcifa ${ }^{2}$}

${ }^{1}$ Laboratório de Ictiologia de Ribeirão Preto, Departamento de Biologia, Universidade de São Paulo - USP, Avenida Bandeirantes, 3900, Monte Alegre, CEP 14040-901, Ribeirão Preto, SP, Brazil

${ }^{2}$ Laboratório de Limnologia, Departamento de Biologia, Universidade de São Paulo - USP, Avenida Bandeirantes, 3900, Monte Alegre, CEP 14040-901, Ribeirão Preto, SP, Brazil *e-mail: andre.esguicero@gmail.com

Cite as: Esguícero, A.L.H. and Arcifa, M.S. Effects of dredging and macrophyte management on the fish species composition in an old Neotropical reservoir. Acta Limnologica Brasiliensia, 2017, vol. 29, e4.

Abstract: Aim: As part of the remodeling of an almost century-old dam, in the Rio Jacaré-Guaçu, the dredging and management of macrophytes were carried out in the Gaviáo Peixoto Reservoir (São Paulo State, Brazil). Data for the reservoir and a river stretch upstream the reservoir were compared, for evaluating the effects of the management procedures. Methods: The fish fauna and physical and chemical factors were studied during five years, before (2005-2006) and after the recovery procedures (2007-2009), once a year, during the rainy season. Fishes were caught by gill nets, $10 \mathrm{~m}$ long and 1.5, 4, and $6 \mathrm{~cm}$-mesh between adjacent knots. Results: After the management procedures, the values of $\mathrm{pH}$ and dissolved oxygen increased in the reservoir, whereas conductivity decreased, bringing them closer to those of the upstream stretch. Species richness, diversity, and Catch per Unit Effort in number and biomass, increased in the reservoir after the management. Conclusions: After the recovery procedures, the composition of the fish fauna in the reservoir was similar to that of the upstream stretch. The dredging and management of macrophytes in the reservoir benefited the fish fauna diversity, through improvement in water quality and space expansion.

Keywords: Upper Rio Paraná basin; antrophic impacts; hypoxia; Neotropical ichthyofauna.

Resumo: Objetivo: Como parte da modernização de uma barragem quase centenária no Rio Jacaré-Guaçu, foram realizados o desassoreamento e o manejo de macrófitas no reservatório da PCH Gaviáo Peixoto (Estado de São Paulo, Brasil). Dados do reservatório e de um trecho do rio, a montante do reservatório, foram comparados, para avaliar os efeitos do manejo. Métodos: A ictiofauna e condiçôes físicas e químicas foram estudadas durante cinco anos, antes (2005-2006) e depois do processo de recuperação (2007-2009), uma vez ao ano, na estação chuvosa. Os peixes foram coletados com rede de espera, de $10 \mathrm{~m}$ de comprimento e com malhas de 1.5, 4 e $6 \mathrm{~cm}$ entre nós adjacentes. Resultados: Após o manejo de macrófitas e desassoreamento, os valores de $\mathrm{pH}$ e de oxigênio dissolvido elevaram-se e os de condutividade diminuíram no reservatório, aproximando-os daqueles do trecho a montante. A riqueza de espécies, a diversidade e a Captura por Unidade de Esforço em número e biomassa, aumentaram no reservatório após o manejo. Conclusóes: Depois dos procedimentos de recuperação, a composição da ictiofauna do reservatório foi semelhante à do trecho a montante. O desassoreamento e manejo de macrófitas no reservatório foram benéficos para a diversidade da ictiofauna, por melhorar a qualidade da água e pela ampliação do espaço.

Palavras-chave: Bacia do alto Rio Paraná; impactos antrópicos; hipóxia; ictiofauna Neotropical. 


\section{Introduction}

The freshwater fish fauna represents about $24 \%$ of the global vertebrate diversity (Nelson et al., 2016). With over than 10,000 valid species (Eschmeyer \& Fong, 2015), and an increasing number of new taxa, the greatest taxonomic diversity of this group is housed in tropical latitudes (Winemiller et al., 2008). Despite the expressive representation and importance in the global biodiversity, in the last decades the freshwater fish fauna has been progressively depleted by anthropic actions, with over $30 \%$ of the species in an extinction process (IUCN, 2015).

According to Dudgeon et al. (2006), several factors can be pointed out as threats to the global freshwater biodiversity, which can be grouped into five interacting categories: overexploitation, water pollution, flow modification, destruction or degradation of habitat, and introduction of alien species. The impoundment of a river, and consequent formation of a reservoir, is an anthropic action that, over time, could comprise almost all these interacting categories. The damming of a river involves several environmental changes, and the alterations in flow conditions are the most drastic consequences observed (reviewed in Agostinho et al., 2008). In general, changes caused by this kind of human intervention are so deep that the process may be equivalent to the formation of a new ecosystem (Baxter, 1977), with severe changes in the abundance and composition of species (Agostinho et al., 2008). Usually, species that present generalist behavior in relation to reproduction and food requirements tend to show a marked population increase, while species with more specific requirements, such as some migratory fish species, show a trend to reduction or even local population extinction (Agostinho et al., 2007a).

The retention of sediment and nutrients are some of the main consequences of the alterations in flow conditions by rivers' impoundment (Agostinho et al., 2007a), and siltation is one of the most dominant aging processes of reservoirs (Miranda, 2001). Siltation reduces the heterogeneity of habitats related to the depth, and drastically alters the characteristic of the bottom and littoral habitats (Allan \& Castillo, 2007), reducing the fish production and diversity (Berkman \& Rabeni, 1987). Another important consequence of the alterations in flow conditions is a growing community of primary producers, especially species of floating macrophytes (Agostinho et al., 2007b).
It is known that a moderate colonization of macrophytes can increase the local biodiversity, including fish (Thomaz, 2002; Thomaz \& Cunha, 2010). Macrophyte mats can harbor a high diversity of fishes, especially juvenile ones, which explore these habitats as shelter and feeding sites (Bulla et al., 2011). However, high densities of these plants can produce intolerable conditions for aquatic organisms (Miranda \& Hodges, 2000; Perna et al., 2012), restrictive for fish, especially nocturnal hypoxia generated by the respiration of these plants and associated biota (Frodge et al., 1990).

The Gaviáo Peixoto Reservoir, located in a tributary of the upper Rio Paraná basin, in southeastern Brazil, was silted and covered by macrophyte banks after almost a century after its formation. As part of the remodeling of the Gaviáo Peixoto Dam, the dredging and management of macrophytes were carried out in the reservoir, and the fish fauna of the reservoir was sampled before and after the management procedures. Therefore, this study aimed to evaluate the consequences of the management of a Neotropical reservoir over the fish fauna, considering the environmental abiotic and biotic factors.

\section{Material and Methods}

\subsection{Study area}

Jacaré-Guaçu (Figure 1) is a fourth-order river with a catchment area of approximately $4,108 \mathrm{~km}^{2}$. The natural vegetation of this basin is impacted by anthropic actions, mainly farming and cattle ranching (São Paulo, 2008). The remnants of natural vegetation are mainly composed of seasonal semideciduous and riparian forests and "cerrado" (savanna) (Hueck \& Seibert, 1981). The region has a tropical climate, with a dry season lasting at least three months and the annual mean temperature ranging from 18 to $20^{\circ} \mathrm{C}$ (Nimer, 1989). The river belongs to the upper Rio Paraná basin, its headwaters are located in the Serra de Itaqueri (town of São Carlos, São Paulo State, Brazil), and flows into the Ibitinga Reservoir (Rio Tietê). There are three dams on the Rio Jacaré-Guaçu: Gavião Peixoto Dam, closed in 1913, and Lobo and Santana dams closed in 1936 and 1964, respectively.

The Gavião Peixoto Reservoir (Figure 1, 2), is located near the town of Gavião Peixoto (State of São Paulo), and is a "run-of-the-river" dam. The general characterization of the reservoir is: margins with low declivity and riparian vegetation partially preserved; $c a .95 \mathrm{~m}$ wide; area $77 \mathrm{~km}^{2}$; 
average depth $3 \mathrm{~m}$; volume $0.12 \times 10^{6} \mathrm{~m}^{3}$; muddy substrate containing decomposing organic matter.

This hydroelectric power station is operated by the Companhia Paulista de Força e Luz, which initiated the studies for remodeling the dam and other components, in 2004, aiming the improvement of the dam safety and the optimization of the use of the water resources. At this period, the reservoir was too silted, filled with macrophytes, and with excess of decomposing organic matter in its substrate, being evident the continuous release of gases from the decomposition process.

Before the dam improvement and macrophyte management, during 2005 and 2006, the reservoir was characterized by a central channel of running water and littoral zones densely occupied by
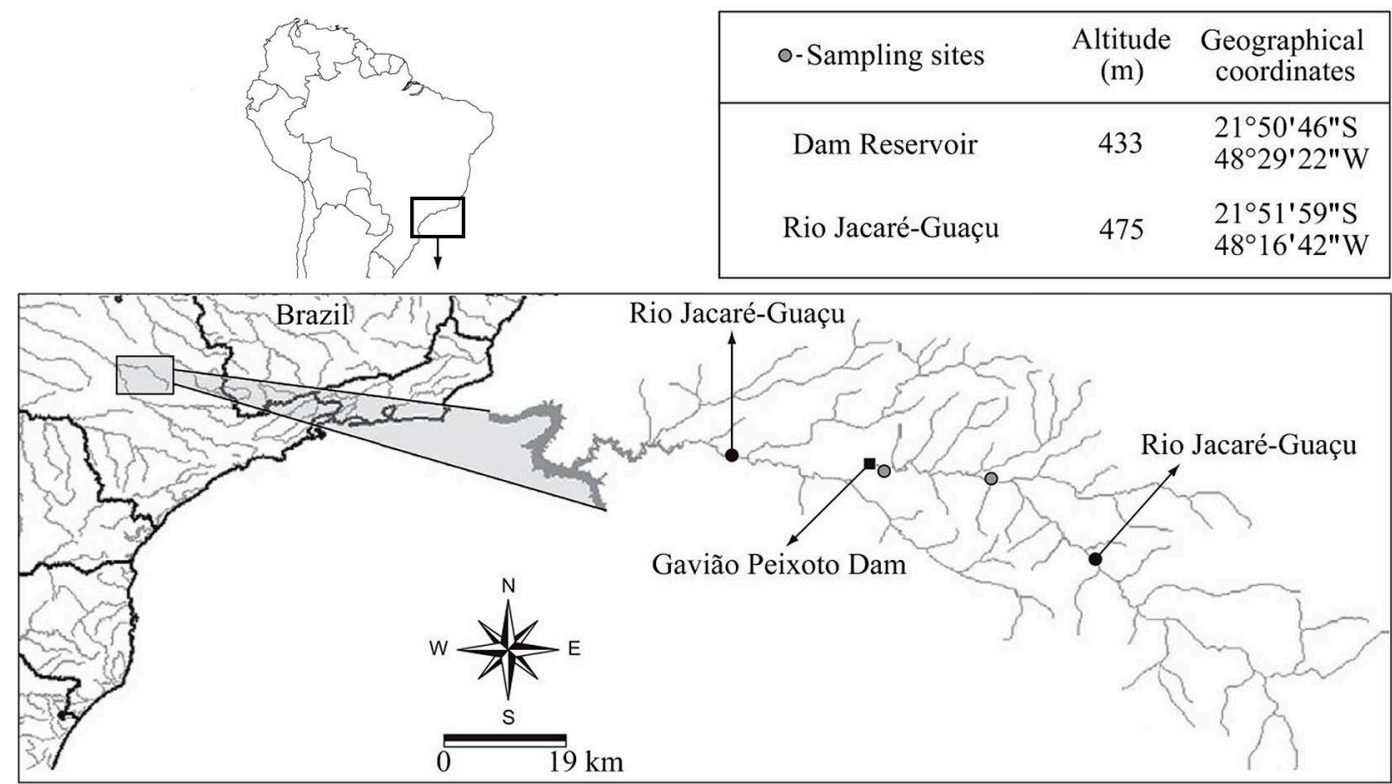

Figure 1. Location of the Rio Jacaré-Guaçu basin in Brazil, South America, with the studied stretch in detail.
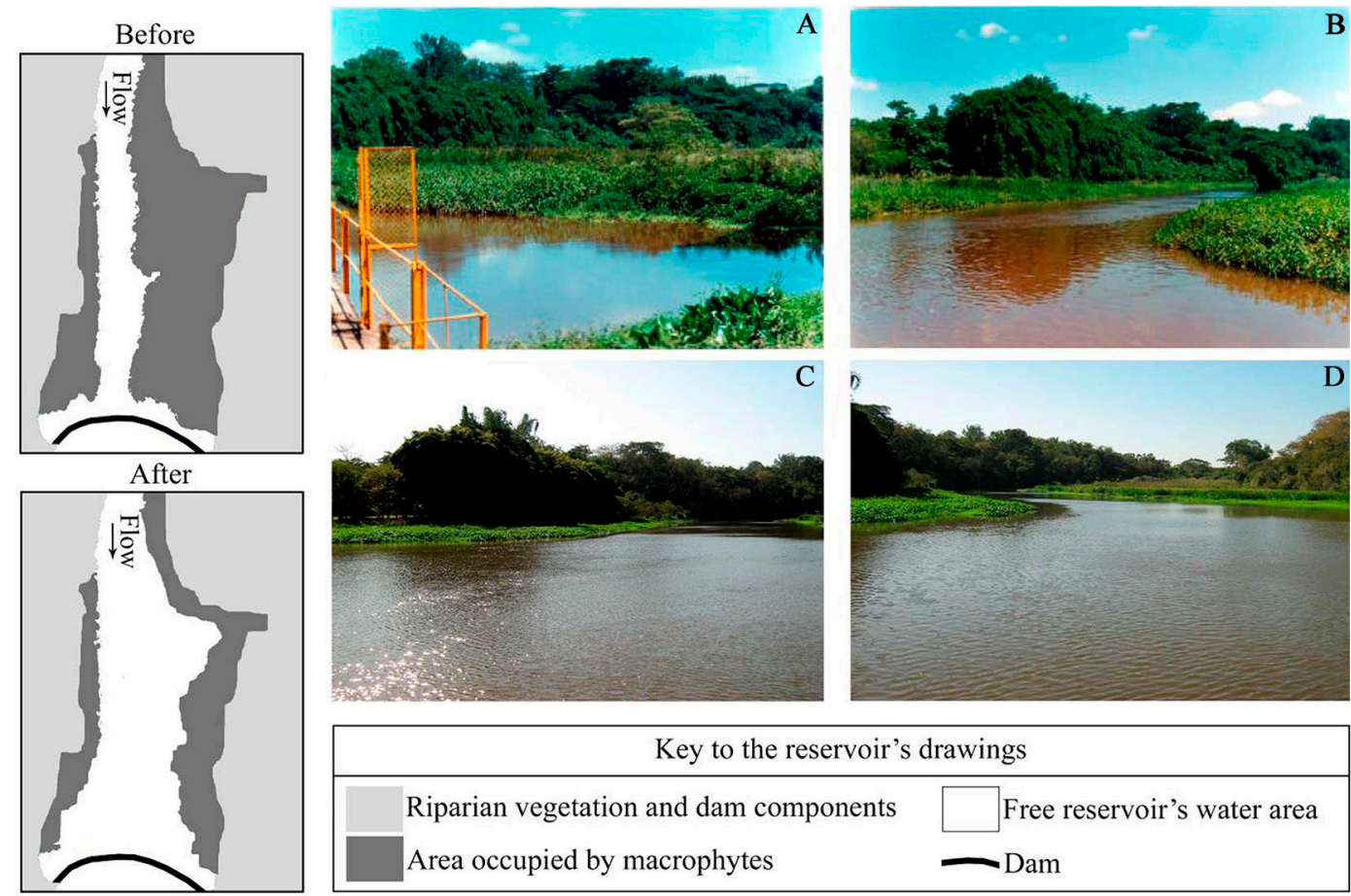

Figure 2. Gaviāo Peixoto Reservoir before (A and B; 2005) and after (C and D; 2008) the dredging and management of macrophytes. 
macrophytes (Figure 2), with predominance of three species: Typha domingensis Pers., Eichhornia azurea Kunth., and Echinochloa crusgalli (L.) P. Beauv. var. crusgalli. After the dam's improvement, performed in the summer of 2006-2007, with the dredging and mechanical removal of macrophyte mats, the reservoir was characterized by a wider free water area, composed of a semi-lentic pelagic zone and a lentic littoral one, which was partially occupied by macrophytes (Figure 2), with predominance of seven species: Salvinia auriculata Aubl., Salvinia biloba D. Mitch., Pistia stratiotes L., Floscopa glabrata (Kunth), E. azurea, T. domingensis, and Urochloa spp.

\subsection{Sampling}

According to Esguícero \& Arcifa (2010), the fish migration between the reservoir and the downstream sites of the Jacaré-Guaçu River is very low, so, in addition to the reservoir, only a section of the river upstream the reservoir was studied. Since it was expected that the management in the reservoir would determine changes in fish composition and abiotic factors resembling the upstream river, the upstream section of the river was included in the sampling design. This upstream lotic habitat is characterized by: margins with low declivity and riparian vegetation partially preserved; river banks covered by Poaceae (e.g., Urochloa spp.); $25 \mathrm{~m}$ wide; substrate type muddy-sandy; littoral zone with an average depth of $1.4 \mathrm{~m}$.

Samplings were carried out once a year during the rainy-season, in early December, from 2005 to 2009, at both habitats, the reservoir and the upstream section of the river (Figure 1). The fish samplings were carried out with $10 \mathrm{~m}$ long gill nets with $1.5,4.0$, and $6.0 \mathrm{~cm}$-mesh, between adjacent knots. The effort was standardized and similar at each station. The gill nets were placed at sunset, for $c a .15$ hours at both habitats. The specimens were fixed in $10 \%$ formalin immediately after their capture, and transferred to $70 \%$ ethanol. Specimens were deposited at the Laboratório de Ictiologia de Ribeirão Preto (LIRP) of the Departamento de Biologia da Faculdade de Filosofia, Ciências e Letras de Ribeirão Preto, Universidade de São Paulo, Brazil (for information on Voucher specimens see Esguícero \& Arcifa, 2011).

The temperature, dissolved oxygen, electrical conductivity, and $\mathrm{pH}$, were measured in the surface water, in the evening, around 15:00, with Yellow Springs Inc. equipment, models 95, 30, and 60, respectively. The macrophyte composition and relative cover was characterized visually.

\subsection{Data analysis}

The Catch Per Unit Effort (CPUE) was used to express the fish abundance in number of individuals (CPUE-N) and biomass (CPUE-kg). The effort unit was standardized as the number of fish caught per $10 \mathrm{~m}^{2}$ of gill net sampling for $24 \mathrm{~h}$.

The Shannon-Wiener Index ( $\left.H^{\prime}\right)$ was used for the diversity analyses, the species richness was the number of species in each sample, and the evenness index used was the $\mathrm{E}_{\mathrm{var}}$ (detailed by Tuomisto, 2012), which, according to Smith \& Wilson (1996), is an index independent of species richness.

The average values of CPUE-N, CPUE-kg, $\mathrm{H}^{\prime}, \mathrm{E}_{\mathrm{var}}$ and richness were calculated for the period before (2005 and 2006) and after (2007 to 2009) the dredging and management of macrophytes in the reservoir. The statistical significance of the differences between the average values was obtained by the Student's $t$-test.

The fish fauna similarity between the two studied periods and two habitats were evaluated with the Jaccard index (J'). All the statistical analyses were performed using the statistical program Past 3.12 (Hammer et al., 2013).

\section{Results}

In 2005 and 2006, before the dredging and management of macrophytes, the abiotic features of the Gavião Peixoto Reservoir were too different from the ones observed in the Rio Jacaré-Guaçu (Table 1). The reservoir was characterized by high conductivity values $(\mathrm{t}=8.73, \mathrm{p}=0.012)$, a more acid $\mathrm{pH}(\mathrm{t}=19.79, \mathrm{p}=0.003)$, and lower concentrations of dissolved oxygen during the day $(t=6.08, p=0.026)$.

Table 1. Average values of conductivity $\left(\mu \mathrm{S} . \mathrm{cm}^{-1}\right), \mathrm{pH}$, dissolved oxygen (D.O., mg. $\left.\mathrm{L}^{-1}\right)$, temperature $\left({ }^{\circ} \mathrm{C}\right)$, Catch Per Unit Effort in number of specimens (CPUE-N) and in biomass (CPUE-kg), species richness, diversity $\left(\mathrm{H}^{\prime}\right)$ and evenness $\left(\mathrm{E}_{\mathrm{var}}\right)$ indices, in the Rio Jacaré-Guaçu and in the Gavião Peixoto Reservoir before and after the dredging and management of macrophytes.

\begin{tabular}{lccccc}
\hline & \multicolumn{2}{c}{ Reservoir } & & \multicolumn{2}{c}{ Rio Jacaré-Guaçu } \\
\cline { 2 - 3 } \cline { 5 - 6 } & Before & After & & Before & After \\
\hline Conductivity & 86.9 & 60.2 & & 47.2 & 54.9 \\
pH & 5.25 & 6.6 & 6.7 & 6.4 \\
D.O. & 4.5 & 6.9 & 7 & 7.2 \\
Temperature & 23.6 & 25.6 & 24.6 & 24.9 \\
CPUE-N & 49.5 & 161.3 & 143 & 168.7 \\
CPUE-Kg & 2.5 & 4 & 5.6 & 5.1 \\
Richness & 6.5 & 14.7 & 16 & 13.7 \\
H' & 1.6 & 2.1 & 2.4 & 2.1 \\
$\mathrm{E}_{\text {var }}$ & 0.6 & 0.5 & 0.7 & 0.7 \\
\hline
\end{tabular}


From 2007 onwards, after the dredging and management of macrophytes, the conductivity, $\mathrm{pH}$ and dissolved oxygen concentrations recorded in the reservoir (Table 1) became more similar to the ones recorded in the Rio Jacaré-Guaçu ( $\mathrm{t}=2.44, \mathrm{p}=0.088$; $\mathrm{t}=0.9, \mathrm{p}=0.416 ; \mathrm{t}=0.58, \mathrm{p}=0.587$; respectively).

In the Rio Jacaré-Guaçu, 22 fish species were collected before and after the revitalization of the reservoir, belonging to four orders and 13 families (Table 2). At the reservoir station, before the dredging and management of macrophytes, eight species were collected, belonging to three orders and six families. However, after the recovery procedures 16 fish species were collected in the reservoir, distributed in four orders and 12 families. The number and biomass of fish caught increased in the reservoir after the dredging and management of macrophytes (Table $1 ; \mathrm{t}=4.73, \mathrm{p}=0.018 ; \mathrm{t}=14.23$, $\mathrm{p}<0.001$; respectively). In 2005 and 2006, both CPUE-N and CPUE-kg of fish in the reservoir were lower than the observed in the river $(\mathrm{t}=30.74$, $\mathrm{p}=0.001 ; \mathrm{t}=5.09, \mathrm{p}=0.036$; respectively), but from 2007 to 2009, the CPUE values in the reservoir increased, reaching levels similar to those recorded

Table 2. Taxonomic list of the fish fauna and the occurrence of species before (B) and after (A) the dredging and macrophyte management.

\begin{tabular}{|c|c|c|c|c|}
\hline \multirow{2}{*}{ Taxons } & \multicolumn{2}{|c|}{ Reservoir } & \multicolumn{2}{|c|}{ Rio Jacaré-Guaçu } \\
\hline & B & $\mathbf{A}$ & B & $\mathbf{A}$ \\
\hline \multicolumn{5}{|l|}{ Order Characiformes } \\
\hline \multicolumn{5}{|l|}{ Family Anostomidae } \\
\hline Leporinus friderici (Bloch, 1794) & $\bullet$ & - & $\bullet$ & $\bullet$ \\
\hline \multicolumn{5}{|l|}{ Family Bryconidae } \\
\hline Salminus hilarii Valenciennes, 1850 & & - & - & - \\
\hline \multicolumn{5}{|l|}{ Family Characidae } \\
\hline Astyanax altiparanae Garutti and Britski, 2000 & - & - & - & - \\
\hline Astyanax fasciatus (Cuvier, 1819) & - & - & - & - \\
\hline Moenkhausia sanctafilomenae (Steindachner, 1907) & & & - & - \\
\hline Oligosarcus pintoi Amaral Campos, 1945 & & - & - & \\
\hline \multicolumn{5}{|l|}{ Family Serrasalmidae } \\
\hline Serrasalmus maculatus Kner, 1858 & & - & - & • \\
\hline \multicolumn{5}{|l|}{ Family Curimatidae } \\
\hline Cyphocharax modestus (Fernández-Yépez, 1948) & & - & - & - \\
\hline Cyphocharax nagelii (Steindachner, 1881) & & & - & - \\
\hline Steindachnerina insculpta (Fernández-Yépez, 1948) & & - & - & - \\
\hline \multicolumn{5}{|l|}{ Family Erythrinidae } \\
\hline Hoplias malabaricus (Bloch, 1794) & - & - & - & $\bullet$ \\
\hline \multicolumn{5}{|l|}{ Family Prochilodontidae } \\
\hline Prochilodus lineatus (Valenciennes, 1837) & $\bullet$ & - & - & - \\
\hline \multicolumn{5}{|l|}{ Order Gymnotiformes } \\
\hline \multicolumn{5}{|l|}{ Family Gymnotidae } \\
\hline Gymnotus aff. carapo Linnaeus, 1758 & - & - & • & • \\
\hline \multicolumn{5}{|l|}{ Family Sternopygidae } \\
\hline Eigenmannia trilineata López and Castello, 1966 & & & - & - \\
\hline Sternopygus macrurus (Bloch and Schneider, 1801) & & & - & - \\
\hline \multicolumn{5}{|l|}{ Order Perciformes } \\
\hline \multicolumn{5}{|l|}{ Family Cichlidae } \\
\hline Geophagus brasiliensis (Quoy and Gaimard, 1824) & & $\bullet$ & $\bullet$ & $\bullet$ \\
\hline \multicolumn{5}{|l|}{ Order Siluriformes } \\
\hline \multicolumn{5}{|l|}{ Family Callichthyidae } \\
\hline Hoplosternum littorale (Hancock, 1828) & - & - & - & - \\
\hline Lepthoplosternum pectorale (Boulenger, 1895) & - & - & - & - \\
\hline \multicolumn{5}{|l|}{ Family Heptapteridae } \\
\hline Pimelodella aff. gracilis (Valenciennes, 1835) & & & - & - \\
\hline Rhamdia quelen (Quoy and Gaimard, 1824) & & - & & - \\
\hline \multicolumn{5}{|l|}{ Family Loricariidae } \\
\hline Hypostomus ancistroides (Ihering, 1911) & & - & - & - \\
\hline Hypostomus nigromaculatus (Schubart, 1964) & & & - & - \\
\hline
\end{tabular}


in the same period in the river $(\mathrm{t}=0.21, \mathrm{p}=0.838$; $t=1.38, p=0.239$; respectively).

The species richness (Table 1 ) in the reservoir was lower than that obtained in the river $(\mathrm{t}=4.61$, $\mathrm{p}=0.044$ ), in 2005 and 2006, but increased after the dredging and management of macrophytes, reaching values similar to that found in the river $(t=0.91, p=0.417)$. The increase of the fish richness was responsible for the significant increase of the diversity index values $(t=4.02, p=0.028)$ observed in the reservoir, since there was no significant alteration of the fish evenness in the reservoir before and after the dredging and management of macrophytes $(\mathrm{t}=1.17, \mathrm{p}=0.325)$.

Before the dredging and management of macrophytes, the fish fauna composition of the reservoir was only $38 \%$ similar to the one observed in the Rio Jacaré-Guaçu. The reservoir was mostly colonized by fishes belonging to the families Callichthyidae, represented by two species, and Gymnotidae, represented by one species (Table 2; Figure 3). After the dredging and management of macrophytes, the reservoir was mostly colonized by fishes of the families Characidae, with four species, and Curimatidae, represented by two species. In fact, after the dredging and management of macrophytes, the reservoir presented a fish fauna with a taxonomic composition $68 \%$ similar to that observed in the river.

\section{Discussion}

According to Kimmel \& Groeger (1984), the aging process of some reservoirs is faster than in natural lakes, due mainly to the larger drainage area and the usual location in rivers that drain watersheds with extensive agricultural activities, siltation being a dominant aging process, as commented by Miranda (2001). The Gavião Peixoto Reservoir is located in the Rio Jacaré-Guaçu, whose catchment area is situated in a Brazilian region with significant agricultural development. This fact may have contributed to the intense siltation observed in this reservoir after nine decades since its formation, which is a direct cause of depth reduction and loss of habitat heterogeneity (Agostinho et al., 1999). Furthermore, the depth reductions cause changes in bottom hardness and alterations in water quality conditions (Agostinho et al., 1999). The modifications in the reservoir bottom may negatively affect fishes that feed on the substrate, mainly benthic insectivores (Berkman \& Rabeni,

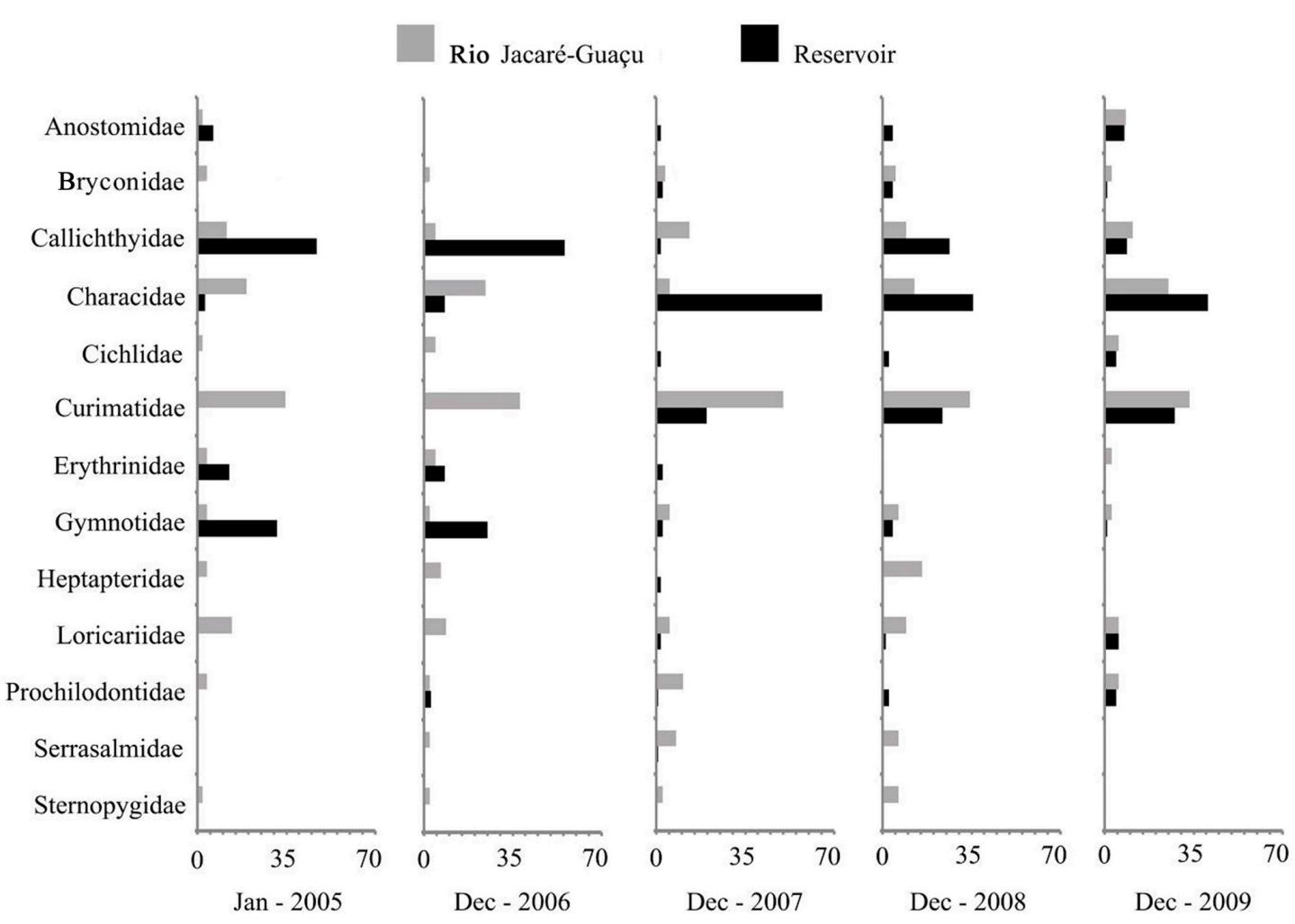

Figure 3. Representativeness, in percentage of the number of specimens, of the fish Families captured in the Gavião Peixoto Reservoir before and after the dredging and management of macrophytes. 
1987). The silt imported from a drainage area with intensive agricultural development, as the catchment area of the Rio Jacaré-Guaçu, is very rich in nutrients and organic matter, which can enhance the primary production, leading, consequently, to a sediment eutrophication scenario (Agostinho et al., 1999). The sediment eutrophication and consequent increased oxygen demands could affect directly and indirectly the fish populations.

Another negative characteristic of the Gavião Peixoto Reservoir was the high density of macrophytes. The aquatic macrophytes are essential components of the river biodiversity, with great influence over physical and chemical characteristics of the environment (Thomaz, 2002; Petry et al., 2003; Agostinho et al., 2007b; Thomaz \& Cunha, 2010), but at high densities, they impact significantly the water quality. The dense coverage of macrophytes in a reservoir can induce clear changes in water temperature, $\mathrm{pH}$, conductivity, and dissolved oxygen concentrations (Frodge et al., 1990). On a diel cycle, strong fluctuations in oxygen and temperature can occur in a reservoir, with the possibility of establishment of anoxic zones at night (Frodge et al., 1990; Miranda \& Hodges, 2000). Therefore, high densities of macrophytes can change the water quality, resulting in unsuitable conditions for fishes, besides reducing the efficiency of foraging by predators, leading to exacerbated competitive interaction of prey (Miranda et al., 2000).

Until the summer of 2006-2007, the Gavião Peixoto Reservoir was a predominantly silted environment, with high conductivity values, acid $\mathrm{pH}$, low concentrations of dissolved oxygen, and littoral zones densely occupied by few species of macrophytes. This environment sheltered a poor ichthyofauna in comparison with a near section in the Rio Jacaré-Guaçu, composed by eight fish species but with predominance of only three species, all recognized as tolerant to environments with low concentrations of oxygen (Petry et al., 2013), two representatives of the Family Callichthyidae (Lepthoplosternum pectorale and Hoplosternum littorale) and one of the Family Gymnotidae (Gymnotus aff. carapo).

The callichthyids are a group of 200 valid species (Eschmeyer \& Fong, 2015), distributed in all the major South American river basins. All the representatives of this group are obligatory air-breathers (Reis et al., 2003); in H. littorale, the air collected at the surface is swallowed and passes through the intestine, an air breathing accessory organ, and is expelled through the anus
(Jucá-Chagas \& Boccardo, 2006). The building of an elaborated floating nest, constructed with parts of plants and bubbles by males (Nico \& Muench, 2004), is one of the features of the reproductive biology of this species, males defending the nest with the aid of their enlarged pectoral spines (Winemiller, 1987).

Gymnotus aff. carapo belongs to the order Gymnotiformes, a group of 205 valid species (Eschmeyer \& Fong, 2015), restricted to the Neotropical continental watersheds (Albert, 2001), that present the notable capacity to produce and detect electric fields (Lissmann, 1958). This species has a bimodal respiration, facultatively breathing air, and has a posterior chamber of the swim bladder greatly elongated and highly vascularized (Liem et al., 1984). The reproductive strategies include nesting behavior, with the formation of a depression on the bottom of shallow water bodies in which eggs are guarded (Crampton et al., 2005), and parental care in the male sex, with mouth breeding of newly hatched embryos (Kirschbaum \& Schugardt, 2002).

Therefore, the representatives of the most abundant groups in the Gavião Peixoto Reservoir presented adaptive features to cope with hypoxia in the waterbody. Due to the lower oxygen availability in the water, in comparison with air, and the viscosity of water, which increase the acquisition costs, the oxygen availability has great influence on the migration and distribution of Neotropical fish (Kramer, 1983). According to Kramer (1987), the oxygen availability limits the fish activity, influencing the amount of energy for locomotion, growth and reproduction, which may result in behavioral responses by fish and changes in activity. The result can be an increase in the use of surface water and air breathing, and changes in vertical or horizontal habitat. Therefore, lower oxygen concentration in the Gavião Peixoto Reservoir, before the recovery procedures, could be the main factor that determined the fish fauna composition.

Another common feature observed among the representatives of the most abundant groups in the reservoir is the nesting behavior and parental care. In hypoxic habitats of Neotropics, where juvenile fish are submitted to severe environmental conditions for growth, a high concentration of species that presents post-spawning parental care is common (Machado-Allison, 1992), which suggests that parental care behavior may act as a compensation factor against the negative impacts of hypoxia over the juvenile fish survival (Reardon \& Thibert-Plante, 2010). 
After the dredging and management of macrophytes in the Gavião Peixoto Reservoir, the habitat turned into a wider free water area, consisting of a semi-lentic pelagic zone and a lentic littoral one, occupied by macrophyte beds with higher species richness. The physical and chemical characteristics of this habitat were restored, including the dissolved oxygen concentrations, which have become more similar to the ones observed in the Rio Jacaré-Guaçu. The procedures of dredging and management of macrophytes enhanced the fish diversity and the taxonomic representativeness in the reservoir, increasing the abundance of the Families Characidae (represented by four species) and Curimatidae (represented by two species). This new taxonomic composition in the reservoir is comparable to the fish fauna found in studies in the same area and in other tributaries of the upper Rio Paraná basin (Castro et al., 2003, 2004, 2005; Langeani et al., 2007; Meschiatti \& Arcifa, 2009; Esguícero \& Arcifa, 2011). All the data discussed in this study point to a partial recovery of the Rio Jacaré-Guaçu, in the Gavião Peixoto Reservoir area, assuming that a total recovery of the Rio Jacaré-Guaçu is practically impossible, considering all the impact sources already imposed by anthropic actions and the consequent biodiversity loss.

A corroboration of this partial recovery of the Rio Jacaré-Guaçu, in the Gaviáo Peixoto Reservoir area, was the capture of the species Salminus hilarii after the dredging and management of macrophytes. According to some authors (Luz-Agostinho et al., 2006; Honji et al., 2011), S. hilarii can be used as an environmental indicator, given its status of a top predator and its high degree of environmental selectivity. According to Esguícero \& Arcifa (2010), the Gavião Peixoto Reservoir can serve as a feeding site for some migratory fish, as the species $S$. hilarii.

The current use of aquatic resources by human population has imposed a wide range of impacts over freshwater ecosystems, generating an urgent need of conservation and restoration of these ecosystems, mainly for avoiding the loss of biodiversity and benefits of the ecosystem for human population (Allan \& Castillo, 2007). All over the world, river fragmentation and deterioration by dams have become common, mostly for power generation (Agostinho et al., 2005). In Brazil, documented actions of freshwater ecosystems restoration are scarce, and considering a future growth of all kinds of aquatic resource demands by human population, any initiative aiming to the recovery and conservation of freshwater ecosystems should be encouraged and disseminated.

\section{Acknowledgements}

We thank all the people who have helped in the field work, CPFL Energy for logistical support, RMC Castro and the Laboratório de Ictiologia de Ribeirão Preto (LIRP), Universidade de São Paulo, Ribeirão Preto. ALHE is financed by the National Program of Post Doctoral from Coordenação de Aperfeiçoamento de Pessoal de Nível Superior (PNPD/CAPES; process no 23038.008118/201034). We also thank the Programa de Pós-Graduação em Biologia Comparada da Universidade de São Paulo for financial support.

\section{References}

AGOstinHO, A.A., GOMES, L.C. and PELICICE, F.M. Ecologia e manejo de recursos pesqueiros em reservatórios do Brasil. Maringá: EDUEM, 2007a, $501 \mathrm{p}$.

AGOSTINHO, A.A., PELICICE, F.M. and GOMES, L.C. Dams and the fish fauna of the Neotropical region: impacts and management related to diversity and fisheries. Brazilian Journal of Biology = Revista Brasileira de Biologia, 2008, 68(4, Suppl), 1119-1132. PMid:19197482. http://dx.doi.org/10.1590/S151969842008000500019 .

AGOSTINHO, A.A., THOMAZ, S.M., GOMES, L.C. and BALTAR, S.L.S.M.A. Influence of the macrophyte Eichhornia azurea on fish assemblage of the Upper Paraná River floodplain (Brazil). Aquatic Ecology, 2007b, 41(4), 611-619. http://dx.doi. org/10.1007/s10452-007-9122-2.

AGOSTINHO, A.A., MIRANDA, L.E., BINI, L.M., GOMES, L.C., THOMAZ, S.M. and SUZUKI, H.I. Patterns of colonization in Neotropical reservoirs, and prognoses on aging. In J.G. TUNDISI and M. STRASKRABA, eds. Theoretical reservoir ecology and its applications. Leiden: Backhuys Publishers, 1999, pp. 227-265.

AGOSTINHO, A.A., THOMAZ, S.M. and GOMES, L.C. Conservação da biodiversidade em águas continentais do Brasil. Megadiversidade, 2005, 1, 70-78.

ALBERT, J.S. Species diversity and phylogenetic systematics of American knifefishes (Gymnotiformes, Teleostei). 190th ed. Michigan: Museum of Zoology, University of Michigan, 2001, 127 p.

ALLAN, J.D. and CASTILLO, M.M. Stream ecology: structure and function of running waters. Dordrecht: Springer, 2007, $436 \mathrm{p}$.

BAXTER, R.M. Environmental effects of dams and impoundments. Annual Review of Ecology and Systematics, 1977, 8(1), 255-283. http://dx.doi. org/10.1146/annurev.es.08.110177.001351. 
BERKMAN, H. and RABENI, C.F. Effect of siltation on stream fish communities. Environmental Biology of Fishes, 1987, 18(4), 285-294. http://dx.doi. org/10.1007/BF00004881.

BULLA, C.K., GOMES, L.C., MIRANDA, L.E. and AGOSTINHO, A.A. The ichthyofauna of drifting macrophyte mats in the Ivinhema River, upper Paraná River basin, Brazil. Neotropical Ichthyology, 2011, 9(2), 403-409. http://dx.doi.org/10.1590/S167962252011005000021 .

CASTRO, R.M.C., CASATTI, L., SANTOS, H.F., FERREIRA, K.M., RIBEIRO, A.C., BENINE, R.C., DARDIS, G.Z.P., MELO, A.L.A., STOPIGLIA, R., ABREU, T.X., BOCKMANN, F.A., CARVALHO, M., GIBRAN, F.Z. and LIMA, F.C.T. Estrutura e composição da ictiofauna de riachos do rio Paranapanema, sudeste e sul do Brasil. Biota Neotropica, 2003, 3(1), 1-31. http://dx.doi. org/10.1590/S1676-06032003000100007.

CASTRO, R.M.C., CASATTI, L., SANTOS, H.F., MELO, A.L.A., MARTINS, L.S.F., FERREIRA, K.M., GIBRAN, F.Z., BENINE, R.C., CARVAlHO, M., RIBEIRO, A.C., ABREU, T.X., BOCKMANN, F.A., PELIÇÃO, G.Z., STOPIGLIA, R. and LANGEANI, F. Estrutura e composição da ictiofauna de riachos da bacia do rio Grande no estado de São Paulo, sudeste do Brasil. Biota Neotropica, 2004, 4(1), 1-39. http://dx.doi. org/10.1590/S1676-06032004000100006.

CASTRO, R.M.C., CASATTI, L., SANTOS, H.F., VARI, R.P., MELO, A.L.A., MARTINS, L.S.F., ABREU, T.X., BENINE, R.C., GIBRAN, F.Z. and RIBEIRO, A.C. Structure and composition of the stream ichthyofauna of four tributary rivers of the upper Rio Paraná basin, Brazil. Ichthyological Exploration of Freshwaters, 2005, 16, 193-214.

CRAMPTON, W.G., HOPKINS, C.D. and BUTH, D.G. Nesting and paternal care in the weakly electric fish Gymnotus (Gymnotiformes: Gymnotidae) with descriptions of larval and adult electric organ discharges of two species. Copeia 2005, 1, 48-60.

DUDGEON, D., ARTHINGTON, A.H., GESSNER, M.O., KAWABATA, Z., KNOWLER, D.J., LÉVÊQUE, C., NAIMAN, C.J., PRIEURRICHARD, A., SOTO, D., STIASSNY, M.L.J. and SULLIVAN, C.A. Freshwater biodiversity: importance, threats, status and conservation challenges. Biological Reviews of the Cambridge Philosophical Society, 2006, 81(2), 163-182. PMid:16336747. http://dx.doi.org/10.1017/ S1464793105006950.

ESCHMEYER, W.N. and FONG, J.D. Species by family/subfamily [online]. California: Institute for Biodiversity Science and Sustainability, 2015 [viewed 25 Nov. 2015]. Available from: http://research.
Calacademy.org/research/ ichthyology/catalog / SpeciesByFamily.asp/

ESGUÍCERO, A.L.H. and ARCIFA, M.S. Fragmentation of a Neotropical migratory fish population by a century-old dam. Hydrobiologia, 2010, 638(1), 4153. http://dx.doi.org/10.1007/s10750-009-0008-2.

ESGUÍCERO, A.L.H. and ARCIFA, M.S. The fish fauna of the Jacaré-Guaçu River basin, Upper Paraná River basin. Biota Neotropica, 2011, 11(1), 103-113. http:// dx.doi.org/10.1590/S1676-06032011000100010.

FRODGE, J.D., THOMAS, G.L. and PAULEY, G.B. Effects of canopy formation by floating and submergent aquatic macrophytes on the water quality of two shallow Pacific Northwest lakes. Aquatic Botany, 1990, 38(2-3), 231-248. http://dx.doi. org/10.1016/0304-3770(90)90008-9.

HAMMER, Ø., HARPER, D.A.T. and RYAN, P.D. PAST: paleontological statistics software package for education and data analysis, 3.12. Oslo: Palaeontological Association, 2013.

HONJI, R.M., MELlO, P.H., ARAÚJO, B.C., RODRIGUES-FILHO, J.A., HILSDORF, A.W. and MOREIRA, R.G. Influence of spawning procedure on gametes fertilization success in Salminus hilarii Valenciennes, 1850 (Teleostei: Characidae): implications for the conservation of this species. Neotropical Ichthyology, 2011, 9(2), 363-370. http:// dx.doi.org/10.1590/S1679-62252011005000012.

HUECK, K. and SEIBERT, P. Vegetationskarte von Südamerika. Folia Geobotanica, 1981, 17, 90.

INTERNATIONAL UNION FOR CONSERVATION OF NATURE - IUCN. The IUCN red list of threatened species [online]. Cambridge: IUCN, 2015 [viewed 26 Nov. 2015]. Available from: http://www. iucnredlist.org/

JUCÁ-CHAGAS, R. and BOCCARDO, L. The airbreathing cycle of Hoplosternum littorale (Hancock, 1828) (Siluriformes: Callichthyidae). Neotropical Ichthyology, 2006, 4(3), 371-373. http://dx.doi. org/10.1590/S1679-62252006000300009.

KIMMEL, B.L. and GROEGER, A.W. Factors controlling primary production in lakes and reservoirs: a perspective. Lake and Reservoir Management, 1984, 1(1), 277-281. http://dx.doi. org/10.1080/07438148409354524.

KIRSCHBAUM, F. and SCHUGARDT, C. Reproductive strategies and developmental aspects in mormyrid and gymnotiform fishes. The Journal of Physiology, 2002, 96(5-6), 557-566. PMid:14692503.

KRAMER, D.L. Aquatic surface respiration in the fishes of Panama: distribution in relation to risk of hypoxia. Environmental Biology of Fishes, 1983, 8(1), 49-54. http://dx.doi.org/10.1007/BF00004945. 
KRAMER, D.L. Dissolved oxygen and fish behavior. Environmental Biology of Fishes, 1987, 18(2), 81-92. http://dx.doi.org/10.1007/BF00002597.

LANGEANI, F., CASTRO, R.M.C., OYAKAWA, O.T., SHIBATTA, O.A., PAVANELLI, C.S. and CASATTI, L. Diversidade da ictiofauna do Alto Rio Paraná: composição atual e perspectivas futuras. Biota Neotropica, 2007, 7(3), 1-17. http://dx.doi. org/10.1590/S1676-06032007000300020.

LIEM, K.F., ECLANCHER, B. and FINK, W.L. Aerial respiration in the banded knife fish Gymnotus carapo (Teleostei: Gymnotoidei). Physiological Zoology, 1984, 57(1), 185-195. http://dx.doi.org/10.1086/ physzool.57.1.30155979.

LISSMANN, H.W. On the function and evolution of electric organs in fish. The Journal of Experimental Biology, 1958, 35, 156-191.

LUZ-AGOSTINHO, K.D., BINI, L.M., FUGI, R., AGOSTINHO, A.A. and JÚliO JUNIOR, H.F. Food spectrum and trophic structure of the ichthyofauna of Corumbá reservoir, Paraná river Basin, Brazil. Neotropical Ichthyology, 2006, 4(1), 61-68. http://dx.doi.org/10.1590/S167962252006000100005 .

MACHADO-ALLISON, A. Larval ecology of fish of the Orinoco Basin. In W.C. HAMLETT, ed. Reproductive biology of South American vertebrates. New York: Springer, 1992, pp. 45-59.

MESCHIATTI, A.J. and ARCIFA, M.S. A review on the fishfauna of Mogi-Guaçu River basin: a century of studies. Acta Limnologica Brasiliensia, 2009, 21, 135-159.

MIRANDA, L.E. A review of guidance and criteria for managing reservoirs and associated riverine environments to benefit fish and fisheries. In G. MARMULLA, ed. Dams, fish and fisheries: opportunities, challenges and conflict resolutions. Rome: FAO, 2001, pp. 91-138.

MIRANDA, L.E. and HODGES, K.B. Role of aquatic vegetation coverage on hypoxia and sunfish abundance in bays of a eutrophic reservoir. Hydrobiologia, 2000, 427(1), 51-57. http://dx.doi. org/10.1023/A:1003999929094.

MIRANDA, L.E., DRISCOLL, M.P. and ALLEN, M.S. Transient physicochemical microhabitats facilitate fish survival in inhospitable aquatic plant stands. Freshwater Biology, 2000, 44(4), 617-628. http:// dx.doi.org/10.1046/j.1365-2427.2000.00606.x.

NELSON, J.S., GRANDE, T.C. and WILSON, M.V. Fishes of the world. New Jersey: John Wiley \& Sons, 2016, $752 \mathrm{p}$.

NICO, L.G. and MUENCH, A.M. Nests and nest habitats of the invasive catfish Hoplosternum littorale in lake Tohopekaliga, Florida: a novel association with non-native Hydrilla verticillata. Southeastern
Naturalist (Steuben, ME), 2004, 3(3), 451-466. http:// dx.doi.org/10.1656/1528-7092(2004)003[0451:NA NHOT]2.0.CO;2.

NIMER, N. Climatologia do Brasil. Rio de Janeiro: IBGE, 1989, $421 \mathrm{p}$.

PERNA, C.N., CAPPO, N., PUSEY, B.J., BURROWS, D.W. and PEARSON, R.G. Removal of aquatic weeds greatly enhances fish community richness and diversity: an example from the Burdekin River floodplain, Tropical Australia. River Research and Applications, 2012, 28(8), 1093-1104. http://dx.doi. org/10.1002/rra.1505.

PETRY, A.C., ABUJANRA, F., GOMES, L.C., JULIO JUNIOR, J.R. and AGOSTINHO, A.A. Effects of the interannual variations in the flood pulse mediated by hypoxia tolerance: the case of the fish assemblages in the upper Parana River floodplain. Neotropical Ichthyology, 2013, 11(2), 413-424. http://dx.doi. org/10.1590/S1679-62252013005000008.

PETRY, P., BAYLEY, P.B. and MARKLE, D.F. Relationships between fish assemblages, macrophytes and environmental gradients in the Amazon River floodplain. Journal of Fish Biology, 2003, 63(3), 547-579. http://dx.doi.org/10.1046/j.10958649.2003.00169.x.

REARDON, E.E. and THIBERT-PLANTE, X. Optimal offspring size influenced by the interaction between dissolved oxygen and predation pressure. Evolutionary Ecology Research, 2010, 12, 377-387.

REIS, R.E., KULLANDER, S.O. and FERRARIS, C.J. Check list of the freshwater fishes of South and Central America. Porto Alegre: EDIPUCRS, 2003, 742 p.

SÃO PAULO. Governo do Estado. Secretaria de Agricultura e Abastecimento - SAA. Coordenadoria de Assistência Técnica Integral - CATI. Levantamento Cadastral das Unidades de Produção Agropecuária LUPA. Informaçóes e Serviços Derivados do PROJETO LUPA 2007/08 [online]. São Paulo: SAA, 2008 [viewed 15 Jan. 2013]. Available from: http://www. cati.sp.gov.br/projetolupa/

SMITH, B. and WILSON, J.B. A consumer's guide to evenness indices. Oikos, 1996, 76(1), 70-82. http:// dx.doi.org/10.2307/3545749.

THOMAZ, S.M. and CUNHA, E.R. The role of macrophytes in habitat structuring in aquatic ecosystems: methods of measurement, causes and consequences on animal assemblages' composition and biodiversity. Acta Limnologica Brasiliensia, 2010, 22(2), 218-236. http://dx.doi.org/10.4322/ actalb.02202011.

THOMAZ, S.M. Ecological factors associated to aquatic macrophyte colonization and growth and management challenges. Planta Daninha, 2002, 20, 21-33. http://dx.doi.org/10.1590/S010083582002000400003.

TUOMISTO, H. An updated consumer's guide to evenness and related indices. Oikos, 2012, 121(8), 
1203-1218. http://dx.doi.org/10.1111/j.16000706.2011.19897.x.

WINEMILLER, K.O. Feeding and reproductive biology of the currito, Hoplosternum littorale, in the Venezuelan llanos with comments on the possible function of the enlarged male pectoral spines. Environmental Biology of Fishes, 1987, 20(3), 219227. http://dx.doi.org/10.1007/BF00004956.
WINEMILlER, K.O., AGOSTINHO, A.A. and CARAMASCHI, E.P. Fish ecology in tropical streams. In D. DUDGEON, ed. Tropical stream ecology. Oxford: Elsevier, 2008, pp. 107-146.

Received: 26 November 2015 Accepted: 16 February 2017 